\title{
PAKAIAN SERAGAM PERAWAT: SEBUAH RANCANGAN PENELITIAN
}

\author{
Deny Arifiana ${ }^{1}$ (Pascasarjana Pengkajian Seni Pertunjukan dan Seni Rupa Universitas Gadjah Mada) \\ G.R. Lono Lastoro Simatupang ${ }^{2}$ (Pascasarjana Pengkajian Seni Pertunjukan dan Seni Rupa Universitas Gadjah Mada) \\ SP. Gustami ${ }^{3}$ (Pascasarjana Pengkajian Seni Pertunjukan dan Seni Rupa Universitas Gadjah Mada)
}

\begin{abstract}
The nurse's uniform is the main supporter of the nurse in performing her professional roles at the hospital.Therefore, the nurse's uniform is designed to meet the needs of her professional role in the hospital, although in practice the nurse's uniform is not always able to function properly. This article aims to identify the variables that need to be considered in the study of professional uniform design, especially nurses. The hope, this paper can contribute to the design of similar studies. Assessment of the design of nurse uniforms is done through literature and document studies, with the scope of the in-patient nurses' uniforms. This article shows that the variables that need to be considered in the study of professional uniform design, especially the nurse, cover the professional needs and criteria for the design requirements of professional uniform. The stages that need to be done in analyzing the functional design of professional uniform are grouped into 4 stages, including: stage identifying the needs of the profession; determine the functional requirements of the profession; establishing criteria for the design of professional uniforms; and the stage reflects the functional needs of the profession into the clothing design.
\end{abstract}

Key words: uniforms, nurses, design-research

\begin{abstract}
ABSTRAK
Pakaian seragam perawat merupakan pendukung utama perawat dalam menjalankan aktifitas peran profesinya di rumah sakit. Maka dari itu, pakaian seragam perawat dirancang untuk memenuhi kebutuhan profesinya di rumah sakit, kendati pada praktiknya pakaian seragam perawat tidak selalu dapat berfungsi sebagaimana mestinya. Artikel ini bertujuan untuk mengidentifikasi variabel-variabel yang perlu dipertimbangkan dalam penelitian desain pakaian seragam profesi, khususnya perawat. Harapannya, tulisan ini dapat berkontribusi bagi perancangan penelitianpenelitian sejenis. Pengkajian terhadap desain pakaian seragam perawat dilakukan melalui studi literatur dan dokumen, dengan ruang lingkup pada pakaian seragam perawat rawat inap. Tulisan ini menunjukkan bahwa variabel-variabel yang perlu dipertimbangkan dalam penelitian desain pakaian seragam profesi (perawat), mencakup kebutuhan-kebutuhan profesi dan kriteria persyaratan desain pakaian seragam profesi. Adapun tahapan yang perlu dilakukan dalam menganalisis fungsional desain pakaian seragam profesi dikelompokkan ke dalam 4 tahap, meliputi: tahap mengidentifikasi kebutuhan profesi; menetapkan kebutuhan fungsional profesi; menetapkan kriteria desain pakaian seragam profesi; dan tahap merefleksikan kebutuhan fungsional profesi ke dalam desain pakaian.
\end{abstract}

Kata kunci: pakaian-seragam, perawat, rancangan-penelitian 


\section{PENDAHULUAN}

Pakaian seragam merupakan pendukung utama perawat dalam menjalankan aktifitas peran profesinya di rumah sakit, khususnya dalam praktik keperawatan. Penggunaan pakaian seragam perawat, di samping sebagai penunjang aktivitas, juga memiliki fungsi-fungsi lain, antara lain sebagai identitas dan petunjuk terhadap batas-batas peran profesinya di rumah sakit (Timmons dan Linda East, 2010: 261). Pakaian seragam perawat cukup beragam desain dan jenisnya di setiap rumah sakit. Desain pakaian seragam perawat umumnya dibedakan berdasarkan unit kerja dan jenis kelamin pemakainya, kecuali stelan perawat berbentuk 'scrub suit' di Instalasi Gawat Darurat (IGD), Intensive Care Unit (ICU), atau di ruang operasi yang cenderung sejenis. Jenis pakaiannya pun bervariasi, mulai dari terusan berbentuk gaun (dress) hingga stelan yang terdiri dari atasan (top) dan bawahan (bottom) berwujud rok atau celana panjang.

Kebijakan lokal masing-masing rumah sakit kiranya telah memicu perbedaan desain pakaian, jenis pakaian, cara berpakaian, dan cara berpenampilan perawat di rumah sakit. Bahkan, di sejumlah rumah sakit, perawat tidak lagi mengenakan pakaian seragam profesinya, melainkan berpakaian seragam rumah sakit, sejenis dengan pakaian tenaga kesehatan lainnya, sehingga tidak lagi mudah diidentifikasi tanpa adanya petunjuk situasional tertentu. Namun demikian, hingga kini sebagian besar pakaian seragam perawat perempuan masih dilengkapi dengan topi perawat yang identik dengan profesinya, meskipun jenis, bentuk, dan ornamennya berbeda-beda di setiap rumah sakit. Di samping keragaman desain pakaian, terdeteksi pula beberapa persoalan teknis pada pakaian seragam perawat di rumah sakit, antara lain mulai dari bentuk pakaian yang teramat ketat, bergaris leher rendah, bernoda, bau, dan kusut, hingga warna pakaian yang nampak pudar.

Pakaian seragam perawat sejatinya dirancang untuk memenuhi kebutuhan peran profesinya di rumah sakit. Hal ini didasari oleh pernyataan Jennings, bahwa pakaian pada dasarnya digunakan untuk memenuhi kebutuhan manusia (Jenning, 2011: 170-171), meskipun dalam praktiknya tidak selalu sejalan atau bahkan menyimpang dari tujuan awalnya. Realitas ini mengindikasikan bahwa permasalahan pada pakaian seragam perawat cukup kompleks dan problematik, yang apabila diperhatikan dari karakteristiknya merujuk pada persoalan fungsional, informasi, dan nilai visual, seperti halnya permasalahan umum karya desain (Masri, 2010: 35-36). Hal inilah yang pada akhirnya membuat pakaian seragam perawat menjadi menarik untuk dikaji, terutama terhadap permasalahan fungsional pakaian, yang notabene dapat berdampak pada kenyamanan aktifitas atau sikap kerja perawat di rumah sakit (Antia, et al., 2016: 49-54).

Artikel ini bertujuan untuk mengidentifikasi variabel-variabel terpenting yang perlu dipertimbangkan dalam penelitian desain pakaian seragam profesi, khususnya perawat. Harapannya, tulisan ini mampu memberi kontribusi bagi perancangan penelitian-penelitian sejenis. Pengkajian dilakukan melalui studi pustaka dan dokumen yang terkait dengan pakaian seragam perawat. Ruang lingkup kajian fokus pada desain pakaian seragam perawat rawat inap di rumah sakit, selain dapat mencerminkan profesi perawat, pakaiannya juga rentan terhadap permasalahan fungsional karena dikenakan secara aktif dalam praktik keperawatan di rumah sakit.

\section{PEMBAHASAN}

\section{Pakaian Seragam Perawat}

Perawat merupakan seseorang yang telah lulus pendidikan tinggi keperawatan, baik di dalam maupun di luar negeri yang diakui oleh pemerintah sesuai dengan ketentuan peraturan perundang-undangan (UU RI No. 38, 2014: Pasal 1 Ayat (2)). Perawat memiliki peran dalam menyelenggarakan pelayanan asuhan keperawatan yang disebut praktik keperawatan (UU RI No. 38, 2014: Pasal 1 Ayat (4)); bertanggung jawab dalam mendidik klien, menjadi koordinator asuhan keperawatan, sebagai kolaborator dengan pihak terkait, dan menjadi konsultan dari 
rujukan perawat; serta bertindak sebagai mitra kerja dokter dalam pelayanan keperawatan (Zebua, 2016: 245-246 dan 256). Keberhasilan perawat dalam menyelenggarakan praktik keperawatan di rumah sakit, salah satunya ditunjang oleh penggunaan pakaian kerja berbentuk seragam yang umum di sebut pakaian seragam, yang oleh Hardisurya, et al. (2011: 188). didefinisikan sebagai pakaian yang dirancang khusus untuk dikenakan oleh anggota kelompok atau karyawan perusahaan sebagai bagian dari identitas kelompok atau perusahaan tersebut.

\section{Fungsi dan Kriteria Pakaian Seragam Perawat}

Fungsi merupakan suatu gaya atau cara tindakan desain dalam memenuhi tujuannya (Papanek, 1973: 25). Jennings membagi fungsi pakaian menjadi anti-alergi, perawatan kesehatan, pakaian industri, pelindung, pakaian kerja, dan pakaian seragam, sedangkan menurut kegiatan atau acaranya, pakaian dapat dibedakan menjadi kostum, pakaian klub, pakaian agama, pakaian olahraga, pakaian renang, dan pakaian kerja (Jennings, 2011: 173). Berdasarkan penjabaran tersebut, dapat dijelaskan bahwa 'pakaian seragam' merupakan salah satu fungsi dari pakaian dan perawat mengenakannya untuk kegiatan kerja, sehingga dapat pula disebut sebagai 'pakaian seragam kerja'.

Pada prinsipnya, pakaian seragam perawat harus 'cerdas, aman, dan praktis'. Artinya, pakaian seragam harus dapat: (1) mendukung mobilitas dan memberikan kenyamanan kepada pemakainya; (2) memiliki daya tahan yang baik terhadap pencucian; (3) berkontribusi terhadap identifikasi dengan tujuan untuk keamanan (kode nama, lencana); (4) memproyeksikan citra profesional demi mendorong kepercayaan dan keyakinan publik; (5) berkontribusi terhadap citra yang ingin disajikan, terutama terhadap perusahaan; (6) dirancang dengan mempertimbangkan kelompok klien/pasien dan mencerminkan jenis pekerjaan yang dilakukan; serta (7) mempertimbangkan keamanan tanggung-jawab staf (Royal College of Nurshing (RCN), 2014: 1).

\section{Desain Pakaian}

Desain merupakan pengaturan terhadap garis, bentuk, ruang, warna, dan tekstur menjadi satu kesatuan yang koheren (Marshall, 2004: 267). Elemen-elemen desain menjadi alat bagi desainer untuk menciptakan efek visual dari sebuah pakaian. Elemenelemen desain yang terdiri dari: (1) garis (line); (2) ruang (space), siluet (shape), dan bentuk (form); (3) warna (color); dan (4) tekstur (texture), menjadi dasar dari setiap pekerjaan desain. Elemen-elemen desain tidak memiliki makna praktis terhadap pakaian apabila tidak diintegrasikan dengan prinsip-prinsip pengelolaan desain pakaian (Marshall, et al., 2004: 191-193, 223, dan 249).

\section{Teori Desain Pakaian}

Teori Desain Pakaian 'Model Kebutuhan Konsumen FEA' yang digagas oleh Lamb \& Kallal, menggabungkan pertimbangan fungsional, ekspresif, dan estetika dalam merancang sebuah pakaian, yang disajikan dengan asumsi bahwa pemakainya menginginkan ketiga aspek tersebut dalam pakaian yang mereka kenakan. Aspek fungsional (functional) merupakan persyaratan yang berhubungan dengan kegunaan produk (utilitas), aspek ekspresif (expressive) berhubungan dengan aspekaspek komunikatif atau simbolik suatu produk, dan aspek estetik (aesthetic) berhubungan dengan keinginan manusia terhadap keindahan dan elemen-elemen artistik (Jennings, 2011: 172).

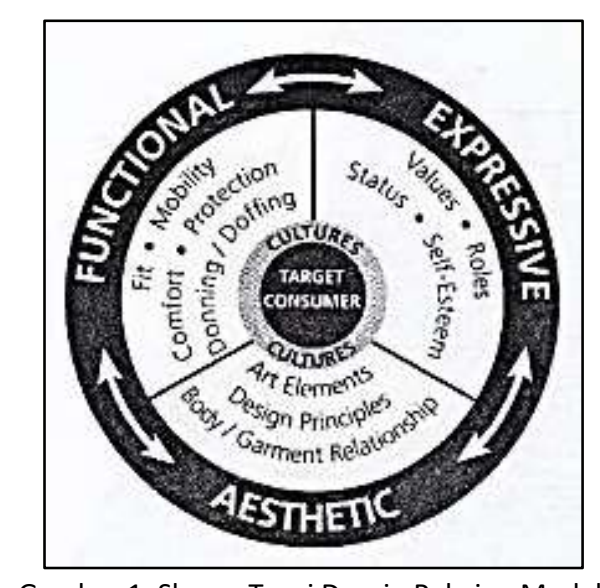

Gambar 1. Skema Teori Desain Pakaian Model Kebutuhan Konsumen FEA Lamb \& Kallal (Jennings, 2011: 172) 


\section{Relasi Desain dengan Fungsi}

Relasi diartikan sebagai: (1) hubungan, pertalian (dengan orang lain); (2) kenalan; dan (3) pelanggan (pelayanan) (https://kbbi.web.id/relasi). Louis Sullivan (1880), pakar desain arsitektur, mengemukakan teorinya "Form Follows Function", yang menegaskan bahwa "bentuk sejatinya dirancang sesuai dengan fungsinya'. Pemikiran tersebut kemudian diikuti oleh Frank Lloyd Wright dengan gagasannya mengenai 'Form and Function are One' (1890), yang menyatakan bahwa 'bentuk dan fungsi' merupakan satu kesatuan. Sejalan dengan itu, Papanek pun berpendapat bahwa tujuan utama dari desain tidak lain untuk memenuhi fungsinya' (Papanek, 1973: 25). Ketiga pemikiran tersebut, kiranya dapat dijadikan pijakan untuk mengatakan bahwa 'desain pakaian' memiliki relasi dengan 'fungsi pakaian', karena 'bentuk pakaian' senyatanya di rancang berdasarkan 'fungsinya' untuk memenuhi kebutuhankebutuhan manusia, dan 'desain' melakukan itu. Maka, dapat dikatakan bahwa 'relasi desain dengan fungsi' terkait dengan peran desain dalam memenuhi kebutuhan manusia terhadap pakaian, yang diterjemahkan ke dalam wujud rancangan pakaian.

\section{Relasi Desain dengan Profesi}

Desainer membangun profil konsumen melalui Informasi demografis dan psikografis, karakteristik fisik, aktivitas, dan preferensi, sehingga dapat diidentifikasi bagaimana kebutuhan dan keinginan konsumen terhadap pakaian, sebagai landasan dalam menetapkan kriteria desain pakaiannya (Jennings, 2011: 172). Bidang pekerjaan atau profesi merupakan salah satu aspek yang diperhitungkan dalam perancangan pakaian (Tain, 2003: 155), termasuk dalam pakaian kerja, untuk mengidentifikasi peran dan aktivitas yang lazim dilakukan, sehingga dapat diketahui ragam kebutuhan profesi terhadap pakaian. Relasi desain dengan profesi mengarah pada peran atau tugas desain dalam mengidentifikasi kebutuhan profesi dan merefleksikannya ke dalam sebuah wujud rancangan pakaian profesi.

\section{Relasi Desain, Fungsi, dan Profesi}

Berdasarkan uraian tersebut dapat dijelaskan bahwa relasi desain, fungsi, dan profesi dalam konteks ini terkait dengan peran desain dalam menjalankan fungsinya untuk memenuhi kebutuhan profesi perawat terhadap pakaian yang dapat menunjang aktifitas peran profesinya, yang diterjemahkan atau direfleksikan ke dalam sebuah rancangan pakaian, melalui pengelolaan elemen-elemen desain pakaian secara tepat menggunakan prinsip-prinsip desain.

\section{Tahap-Tahap Analisis Desain Pakaian Seragam Profesi}

Analisis terhadap relasi-relasi desain pakaian seragam perawat dilakukan dengan cara merefleksikan kebutuhan-kebutuhan fungsional profesi ke dalam elemen-elemen desain menggunakan teori fungsional desain pakaian, dengan tahapan sebagai berikut.

\section{Tahap 1. Mengidentifikasi kebutuhan profesi}

Peran perawat di rumah sakit cenderung berhubungan dengan aktivitas fisik, terutama perawat vokasi yang terlibat aktif dalam penyelenggaraan praktik keperawatan

(http://gustinerz.com/perbedaan-perawatvokasional-profesional-profesional-spesialis/). Hasil identifikasi terhadap persyaratan pakaian staf perawatan kesehatan, dapat diketahui bahwa kebutuhan profesi perawat terhadap pakaian meliputi: kebutuhan terhadap mobilitas, kenyamanan beraktifitas, perlindungan diri, identifikasi profesi, sesuai dengan kelompok klien atau pasien, dan dapat mencerminkan profesi, citra profesional, serta citra perusahaan (RCN: 2014: 1).

\section{Tahap 2. Menetapkan kebutuhan fungsional profesi}

Kebutuhan fungsional pakaian seragam perawat cenderung pada pakaian-pakaian yang memungkinkan dirinya untuk dapat bergerak secara nyaman (mobilitas dan kenyamanan), dapat melindungi dirinya dari berbagai resiko pekerjaan (perlindungan), dan dapat mencerminkan profesinya di mata 
publik (citra profesi). Pada prinsipnya perawat membutuhkan pakaian-pakaian yang dapat menunjang kenyamanan aktivitas peran profesinya di rumah sakit.

\section{Tahap 3. Menetapkan kriteria desain pakaian seragam profesi}

Analisis terhadap fungsional desain pakaian seragam perawat dilakukan dengan landasan teori desain pakaian dengan fokus pada kriteria aspek fungsional desain pakaian, yang terdiri dari: (1) kesesuaian (fit); (2) mobilitas (mobility); (3) kenyamanan (comfort); dan (4) perlindungan (protection); serta teknik pemakaian (donning) atau teknik melepaskan pakaian (doffing) (Jenning, 2011: 172).

\section{Tahap 4. Merefleksikan kebutuhan fungsional profesi ke dalam desain pakaian, meliputi aspek:}

1. Kesesuaian (Fit)

Kesesuaian dalam berpakaian meliputi kesesuaian antara pakaian dengan pemakainya (Marshall, et al., 2004: 311). Sebab itu, pakaian harus disesuaikan dengan: karakteristik fisik (jenis kelamin, bentuk tubuh, jenis dan warna kulit), jenis profesi, jenis aktifitas, ruang beraktifitas, dan jenis pasien yang ditangani (RCN, 2014: 1), serta keyakinan pribadi bila memungkinkan. Penampilan harus profesional dan mudah diidentifikasi (RCN, 2014: 9). Pada prinsipnya, pakaian harus sesuai dengan kebutuhan pemakainya, baik secara pribadi maupun profesi, agar dapat memberi kesan yang tepat pada pemakainya, sehingga dapat membuat pemakainya tampil penuh percaya diri, yang pada akhirnya dapat berpengaruh positif terhadap sikap kerjanya di rumah sakit.

Tabel 1. Aspek Kesesuaian

\begin{tabular}{|c|c|c|c|}
\hline \multicolumn{4}{|c|}{ Elemen-Elemen Desain Pakaian } \\
\hline $\begin{array}{c}\text { Garis } \\
\text { (Line) }\end{array}$ & $\begin{array}{l}\text { Ruang (Space) } \\
\text { Siluet (Shape) } \\
\text { Bentuk (Form) }\end{array}$ & Warna (Color) & Tekstur (Texture) \\
\hline $\begin{array}{l}\text { Garis-garis desain, seperti: garis } \\
\text { potongan pakaian, garis pinggang, garis } \\
\text { pinggul; garis hias (empire, princess, } \\
\text { yoke), dan garis jahitan, harus sesuai } \\
\text { dengan jenis kelamin, bentuk tubuh, } \\
\text { jenis aktifitas, jenis ruang dan jenis } \\
\text { pasien. }\end{array}$ & $\begin{array}{l}\text { Bentuk pakaian, mulai dari } \\
\text { jenis pakaian, siluet, detail, } \\
\text { hingga ukuran pakaian, } \\
\text { harus sesuai dengan jenis } \\
\text { kelamin, bentuk tubuh, } \\
\text { jenis profesi,jenis aktifitas, } \\
\text { jenis ruang, jenis pasien, } \\
\text { dan keyakinan pribadi. }\end{array}$ & $\begin{array}{l}\text { Warna pakaian mulai dari } \\
\text { jenis warna hingga } \\
\text { kombinasi warna yang } \\
\text { digunakan harus sesuai } \\
\text { dengan: jenis kelamin, } \\
\text { bentuk tubuh, jenis kulit, } \\
\text { warna kulit, jenis profesi, } \\
\text { jenis ruang, dan jenis } \\
\text { pasien. }\end{array}$ & $\begin{array}{l}\text { Tekstur kain sesuai jenis } \\
\text { kelamin \& bentuk tubuh. } \\
\text { Jenis bahan sesuai jenis } \\
\text { kelamin, bentuk tubuh, } \\
\text { jenis aktifitas, ruang } \\
\text { termasuk suhu ruang, \& } \\
\text { jenis pasien. Motif bahan } \\
\text { sesuai dengan jenis } \\
\text { kelamin, bentuk tubuh, } \\
\text { dan jenis pasien. }\end{array}$ \\
\hline Contoh & Contoh & Contoh & Contoh \\
\hline $\begin{array}{l}\text { Garis lurus dapat memberi kesan tegas, } \\
\text { gagah, kuat, sedangkan garis } \\
\text { melengkung memberi kesan sifat } \\
\text { lembut, indah, feminin (Jalin dan Ita A. } \\
\text { Mamdy, tanpa tahun: 14). }\end{array}$ & $\begin{array}{l}\text { Jenis pakaian, seperti gaun } \\
\text { dan rok dapat memberi } \\
\text { kesan feminin pada } \\
\text { wanita. }\end{array}$ & $\begin{array}{l}\text { Warna-warna lembut, } \\
\text { seperti merah muda, biru } \\
\text { muda, hijau muda: } \\
\text { memberi kesan } \\
\text { kewanitaan atau } \\
\text { feminin(Jalin dan Ita A. } \\
\text { Mamdy, tanpa tahun: } 57 \text { ). }\end{array}$ & $\begin{array}{l}\text { Tekstur berkilau seperti } \\
\text { taffeta, satin, dan sutra } \\
\text { memberi kesan pucat, } \\
\text { karena memantulkan } \\
\text { cahaya, memberi tekanan } \\
\text { pada kulit dan bentuk } \\
\text { badan, sehingga hanya } \\
\text { cocok bagi yang berkulit } \\
\text { indah (Jalin dan Ita A. } \\
\text { Mamdy, tanpa tahun: 64). }\end{array}$ \\
\hline
\end{tabular}

\section{Mobilitas (Mobility)}

Mobilitas merupakan kesiapsiagaan untuk bergerak atau gerakan berpindahpindah (https://kbbi.web.id/mobilitas). Agar pakaian dapat menunjang mobilitas perawat, maka pakaian perlu disesuaikan dengan standar minimum pakaian kerja perawat.
Pakaian berjenis apapun harus memungkinkan gerakan terbatas, terutama pada bahu, pinggang, dan pinggul. Sikap tubuh, seperti membungkuk atau menggapai, harus dilakukan tanpa mengorbankan martabat perawat atau pasien. Bahan pakaian harus tahan terhadap proses pencucian 
dengan suhu tertentu untuk pengendalian infeksi. Alas kaki harus nyaman, anti slip, dan menutup rapat jari kaki (RCN: 2014: 4-5). Bentuk pakaian harus praktis (sederhana) dan fungsional, mulai dari jenis pakaian hingga

\section{Kenyamanan (Comfort)}

Kenyamanan diartikan sebagai keadaan

nyaman; kesegaran; dan kesejukan (https://kbbi.web.id/nyaman). Sementara Kolcaba menggambarkan kenyamanan dalam 3 bentuk, meliputi kelegaan, kemudahan, dan transendensi

(http://currentnursing.com/nursing theory/c omfort theory kathy kolcaba.html). Bentuk atau model pakaian yang nyaman dalam penelitian Antia et al., (2016: 49-52), meliputi (1) pakaian berkerah tinggi dan berkancing; (2) berbentuk celana dan bukan rok; (3) sesuai ukuran tubuh; (4) dinamis saat bergerak; (5) kerudung yang dikenakan tidak jatuh saat melakukan tindakan; (6) tidak mengenakan perhiasan dan sepatu hak tinggi; (7) jahitan pakaian harus baik; (8) pakaian seragam harus bersih, bebas dari bau, bebas lipatan, dan tidak mudah rusak (Collins, 2014); (9) pakaian dan sepatu berbahan alami dan bahan detail pakaian, menggunakan bahan yang tidak kaku agar tidak menghambat keluwesan tubuh, dan dibuat dalam ukuran yang tepat. Teknik pemakaiannya harus praktis pula agar pakaian mudah dikenakan dan dilepaskan.

pakaian seragam karyawan di indutri hospitality seharusnya terdiri dari $55 \%$ polyester dan $45 \%$ wol (Nelson dan Bowen, 2000); serta terlepas dari apapun jenisnya, kain sekurang-kurangnya dapat dipakai selama dua tahun atau 1000 x pencucian (Wowor (2010). Pemilihan kain harus dipertimbangkan pula dari sisi kemudahan perawatan, tidak menyusut, dan tidak mudah berkerut (Jenning, 2011: 174).

Pakaian yang nyaman dapat dijelaskan sebagai pakaian yang dapat memberikan rasa nyaman kepada pemakainya ketika dikenakan, memberikan keleluasaan dalam beraktifitas, dan mudah dikenakan dan dilepaskan. Kenyamanan pakaian dapat dibangun melalui ketepatan dalam pengelolaan desain pakaian, mulai dari pemilihan bentuk, jenis, detail, ukuran, warna, bahan pakaian, hingga teknik pemakaian.

Tabel 3. Aspek Kenyamanan

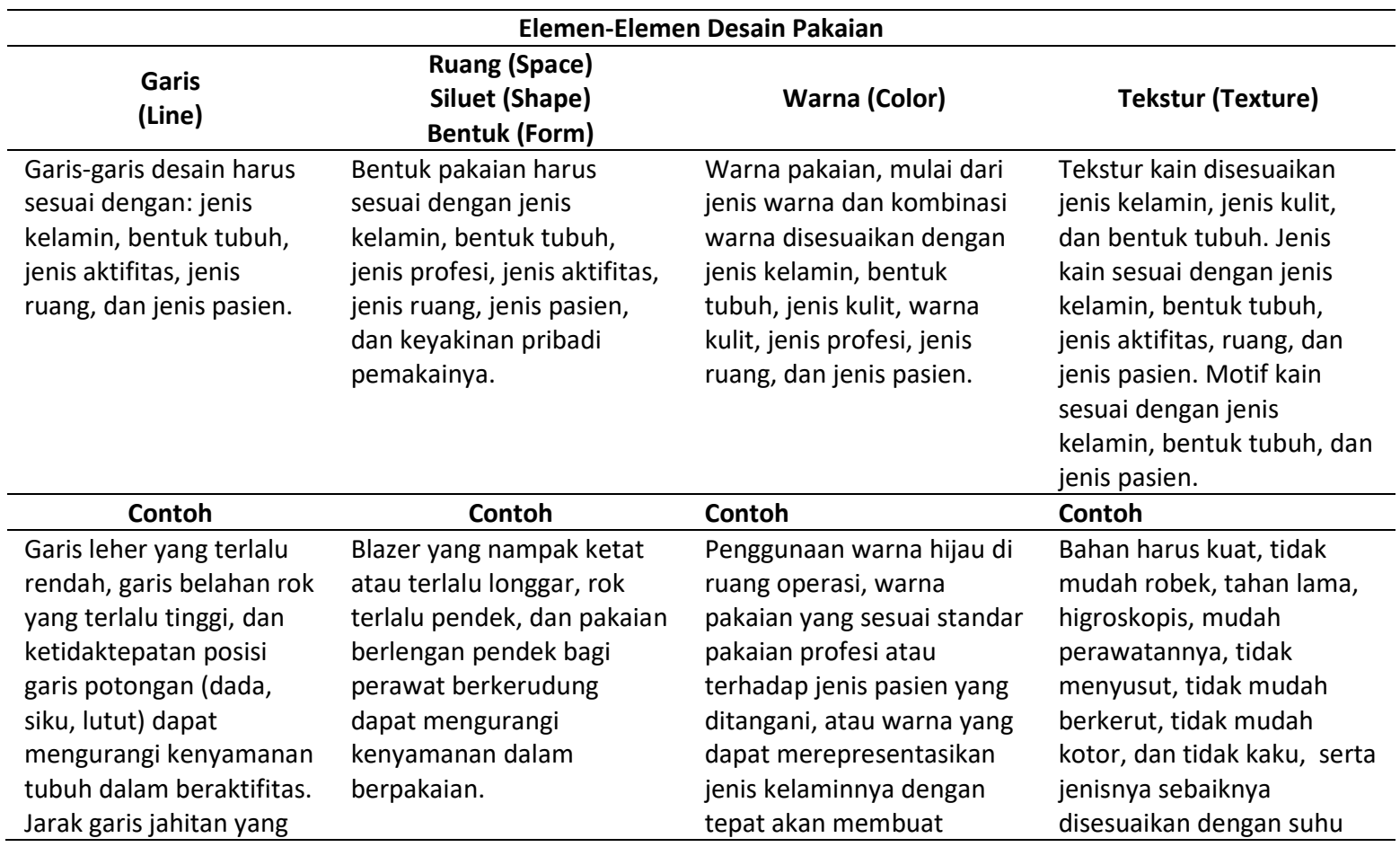


terlalu lebar juga akan

membuat jahitan mudah

terlepas. pemakainya merasa

nyaman. ruangan.

\section{Perlindungan (Protection)}

Perlindungan merupakan perbuatan melindungi (https://kbbi.web.id/lindung). Pakaian merupakan pelindung tubuh pemakainya, oleh karena itu pakaian harus aman ketika dikenakan. Aman dapat dimaknai sebagai bebas dari bahaya atau gangguan (https://kbbi.web.id/aman). Kain seragam harus tahan terhadap proses pencucian dengan suhu air minimal $60^{\circ} \mathrm{C}$ (RCN: 2014: 7). Memiliki daya tahan tertentu, seperti tahan panas atau tidak mudah terbakar dan mudah perawatannya (Jenning, 2011: 174). Pakaian yang aman dapat dipahami sebagai pakaian yang dapat memberikan perlindungan pada tubuh selama beraktifitas dan tidak menimbulkan masalah bagi tubuh ketika dikenakan. Keamanan pakaian dapat tercipta melalui ketepatan pengelolaan desain pakaian, mulai dari pemilihan bentuk, detail, dan garis-garis desain. Pakaian harus dirancang dengan ukuran yang tepat, menggunakan bahan yang aman dengan daya tahan tertentu, tahan terhadap proses pencucian, dan ditunjang dengan teknik pemakaian yang tepat agar pakaian aman dikenakan.

Tabel 4. Aspek Perlindungan

\begin{tabular}{|c|c|c|c|}
\hline \multicolumn{4}{|c|}{ Elemen-Elemen Desain Pakaian } \\
\hline $\begin{array}{l}\text { Garis } \\
\text { (Line) }\end{array}$ & $\begin{array}{c}\text { Ruang (Space), Siluet } \\
\text { (Shape), dan Bentuk (Form) }\end{array}$ & Warna (Color) & Tekstur (Texture) \\
\hline $\begin{array}{l}\text { Garis-garis desain harus } \\
\text { sesuai dengan jenis } \\
\text { kelamin, bentuk tubuh, } \\
\text { jenis aktifitas, jenis ruang, } \\
\text { dan jenis pasien. }\end{array}$ & $\begin{array}{l}\text { Bentuk pakaian harus } \\
\text { sesuai dengan jenis } \\
\text { aktifitas, ruang beraktifitas, } \\
\text { dan jenis pasien, } \\
\text { berpedoman pada standar } \\
\text { pakaian di setiap unit kerja. }\end{array}$ & $\begin{array}{l}\text { Warna pakaian } \\
\text { disesuaikan dengan } \\
\text { standar ruangan (bila } \\
\text { ada), namun warna tidak } \\
\text { berdampak langsung } \\
\text { pada keamanan pemakai. }\end{array}$ & $\begin{array}{l}\text { Tekstur, jenis kain, dan } \\
\text { motif kain (jika ada) } \\
\text { disesuaikan dengan standar } \\
\text { ruang, termasuk dengan } \\
\text { suhu ruang. }\end{array}$ \\
\hline Contoh & Contoh & Contoh & Contoh \\
\hline $\begin{array}{l}\text { Garis jahitan yang terletak } \\
\text { di bagian lengan bawah } \\
\text { atau manset, akan rawan } \\
\text { terbuka jahitan, sehingga } \\
\text { dapat beresiko terpercik } \\
\text { bahan kimia ketika sedang } \\
\text { praktik di Laboratorium } \\
\text { (Lab.) }\end{array}$ & $\begin{array}{l}\text { Panjang lengan pakaian } \\
\text { yang tidak tepat atau tidak } \\
\text { berpenutup, dapat beresiko } \\
\text { terpercik ketika praktik di } \\
\text { Lab. dan detail pakaian } \\
\text { berupa lipit-lipit atau } \\
\text { kerutan berkontribusi } \\
\text { menjadi sarang kuman. }\end{array}$ & - & $\begin{array}{l}\text { Bahan pakaian harus aman } \\
\text { bagi kulit, seperti tidak } \\
\text { memicu reaksi alergi kulit. } \\
\text { Bahan pakaian harus kuat, } \\
\text { tahan gesekan, memiliki } \\
\text { daya tahan yang tepat } \\
\text { terhadap bakteri, proses } \\
\text { pencucian atau perawatan } \\
\text { pakaian, tidak mudah } \\
\text { terbakar, dan tahan } \\
\text { terhadap paparan sinar } \\
\text { radiasi. }\end{array}$ \\
\hline
\end{tabular}

\section{Teknik Pemakaian (Donning) atau Pelepasan Pakaian (Doffing)}

Teknik pemakaian atau pelepasan pakaian perlu dipertimbangkan dalam merancang pakaian, terlebih pada pakaian perawat. Hal ini karena aktifitas perawat membutuhkan pakaian-pakaian yang praktis dan mudah dikenakan atau dilepaskan secara mandiri. Pakaian juga harus mudah dibuka atau ditutup kembali, sehingga perlu dipikirkan jenis penyelesaian pakaian yang akan digunakan sebagai penutup pakaian (closures), seperti halnya resleting, perekat (velcro), atau kancing tekan (Jenning, 2011: 174). 
Tabel 5. Aspek Teknik Pemakaian atau Pelepasan Pakaian

\begin{tabular}{|c|c|c|c|}
\hline \multicolumn{4}{|c|}{ Elemen-Elemen Desain Pakaian } \\
\hline $\begin{array}{c}\text { Garis } \\
\text { (Line) }\end{array}$ & $\begin{array}{l}\text { Ruang (Space) } \\
\text { Siluet (Shape) } \\
\text { Bentuk (Form) }\end{array}$ & Warna (Color) & Tekstur (Texture) \\
\hline $\begin{array}{l}\text { Garis-garis desain harus } \\
\text { sesuai dengan jenis kelamin, } \\
\text { bentuk tubuh, jenis aktifitas, } \\
\text { jenis ruang, dan jenis pasien. }\end{array}$ & $\begin{array}{l}\text { Bentuk pakaian harus } \\
\text { sesuai dengan jenis } \\
\text { aktifitas, ruang } \\
\text { beraktifitas, dan jenis } \\
\text { pasien, dengan } \\
\text { berpedoman pada } \\
\text { standar pakaian di setiap } \\
\text { unit kerja. }\end{array}$ & $\begin{array}{l}\text { Warna pakaian tidak } \\
\text { berdampak pada teknik } \\
\text { pemakaian atau } \\
\text { pelepasan pakaian. }\end{array}$ & $\begin{array}{l}\text { Tekstur, jenis kain, dan motif } \\
\text { kain dapat disesuaikan } \\
\text { dengan standar ruang (bila } \\
\text { ada), namun motif kain tidak } \\
\text { berdampak pada teknik } \\
\text { pemakaian atau pelepasan } \\
\text { pakaian. }\end{array}$ \\
\hline Contoh & Contoh & Contoh & Contoh \\
\hline $\begin{array}{l}\text { Garis-garis desain harus } \\
\text { tepat dalam ukuran dan } \\
\text { posisinya, seperti garis leher } \\
\text { tidak sempit, garis hias tidak } \\
\text { bersinggungan dengan garis } \\
\text { penutup pakaian, dan garis } \\
\text { penutup pakaian tidak } \\
\text { diletakkan pada sisi badan, } \\
\text { karena dapat menghambat } \\
\text { waktu pemakaian atau } \\
\text { pelepasan pakaian. }\end{array}$ & $\begin{array}{l}\text { Bentuk dan detail pakaian } \\
\text { harus dirancang untuk } \\
\text { mudah dikenakan. Bentuk } \\
\text { pakaian yang terlalu } \\
\text { sempit (rok span atau } \\
\text { celana pensil) dapat } \\
\text { mempersulit pemakainya } \\
\text { dalam memakai atau } \\
\text { melepaskan pakaian. }\end{array}$ & $\begin{array}{l}\text { Warna pakaian tidak } \\
\text { berpengaruh terhadap } \\
\text { teknik pemakaian atau } \\
\text { pelepasan pakaian. }\end{array}$ & $\begin{array}{l}\text { Tekstur dan jenis bahan } \\
\text { pakaian harus memungkinkan } \\
\text { pakaian mudah untuk dipakai } \\
\text { atau dilepaskan, tidak mudah } \\
\text { bertiras, tidak mudah } \\
\text { tersangkut, atau tidak } \\
\text { bertekstur timbul, agar } \\
\text { pakaian dapat dibuka atau } \\
\text { ditutup dengan mudah dan } \\
\text { cepat. }\end{array}$ \\
\hline
\end{tabular}

\section{KESIMPULAN}

Berdasarkan hasil analisis terhadap relasi-relasi desain pakaian seragam profesi perawat, maka dapat disimpulkan bahwa:

1. Variabel-variabel yang perlu dipertimbangkan dalam penelitian desain pakaian seragam profesi (perawat), meliputi kebutuhan-kebutuhan profesi dan kriteria persyaratan desain pakaian seragam profesi.

2. Langkah-langkah yang perlu dilakukan dalam penelitian desain pakaian seragam profesi, dikelompokkan ke dalam 4 tahap, meliputi: tahap 1 , mengidentifikasi kebutuhan profesi; tahap 2, menetapkan kebutuhan fungsional profesi; tahap 3, menetapkan kriteria desain pakaian seragam profesi; dan tahap 4, merefleksikan kebutuhan fungsional profesi ke dalam desain pakaian, mulai dari aspek kesesuaian (fit), mobilitas (mobility), kenyamanan (comfort), perlindungan (protection), hingga teknik pemakaian (donning) atau pelepasan pakaian (doffing).

\section{KEPUSTAKAAN}

Antia, Krisna Yetti, dan Tuti Nuraini. 2016. "Kenyamanan Perawat dalam Berpenampilan", dalam Indonesian Journal of Nushing Health Science. Volume 1 Nomor 1, Maret 2016.

Danesi, Marcel. 2010. Pesan, Tanda, dan Makna Buku. Cetakan I. Yogyakarta: Jalasutra.

Hardisurya, Irma, et al. 2011. Kamus Mode Indonesia. Jakarta: PT. Gramedia Pustaka Utama.

Jennings, Tracy. 2011. Creativity in Fashion Design: an Inspiration Workbook. New York: Fairchild Books.

Marshall, Susane G. et al. 2004. Individuality in Clothing Sellection and Personal Appearance. 6th ed. New Jersey: Person Prentice Hall.

M.Jalins dan Ita. A. Mamdy. Tanpa tahun. Unsur-Unsur Pokok dalam Seni Pakaian. Bandung: ASTANT.

Masri, Andri. 2010. Strategi Visual. Cetakan I. Yogyakarta: Jalasutra.

Royal College of Nurshing (RCN). 2014. "Guidance on Uniform and Work Wear". London: Royal College of 
Nurshing, July 2013, Third Edition, review December 2014.

Stephen Timmons dan Linda East. 2011. "Uniform, Status, and Profesional Boundaries in Hospital", dalam Sociology of Health \& IIIness Vol.33 No. 72011 ISSN 0141-9889, 2011.

Sugiyono. 2011. Metode Penelitian Kuantitatif, Kualitatif, dan R\&D. Bandung: Penerbit Alfabeta.

Tain, Linda. 2003. Portfolio Presentation For Fashion Designers. Second Edition. New York: Fairchild Publications, Inc.

Zebua, Manahati. 2016. Manajemen Rumah Sakit: Fungsikan Manajemen Instalasi di Rumah Sakit. Yogyakarta: Penerbit Valemba.

Papanek, Victor. 1973. Design For The Real World: Human Ecology and Social Change. Toronto/New York/London: Bantam Books.

\section{Webtografi}

Undang-Undang Republik Indonesia Nomor 38 tahun 2014 tentang Keperawatan. Diunduh 02 Januari 2017, pukul 14.00 WIB.

Internet :

http://www.scribd.com/doc/21749163/TeoriArsitektur-Form-FollowsFunction\#scribd

https://kbbi.web.id/relasi. Diakses 15 April 2018

http://gustinerz.com/perbedaan-perawatvokasional-profesional-profesionalspesialis/. Diakses 17 April 2018.

https://kbbi.web.id/aman. Diakses 17 April 2018.

https://kbbi.web.id/lindung. Diakses 17 April 2018

https://kbbi.web.id/mobilitas. Diakses 17 April 2018

http://currentnursing.com/nursing theory/co mfort theory kathy kolcaba.html.

Diakses 17 April 2018. 